\title{
Teknokultura
}

ISSNe: 1549-2230

http://dx.doi.org/10.5209/TEKN.59078

\section{Auroville: city of the dawn, city of the future, now}

\author{
Ian Parker ${ }^{1}$
}

Recibido: 22 de febrero de 2018 / Aceptado: 22 de agosto de 2018 Open peer reviews

\begin{abstract}
This paper briefly describes the formation, present-day functioning and problems facing the futuristic city 'Auroville' in the state of Tamil Nadu in south India. Founded in 1968 as a 'universal' city, and planned to have 50,000 inhabitants that would, its founders declared, take the next step in human evolution to exist as a self-sustaining community independent of nation states. Auroville manifests another utopian attempt to create a 'common' space which resonates with communist hopes to reclaim the commons from capitalist enclosure. This paper explores the problems that face Auroville when it creates its 'commons' on existing peasant land and so becomes implicated in colonial politics.
\end{abstract}

Keywords: commons; colonialism; south India; Sri Aurobindo; utopian communities.

\section{[es] Auroville: ciudad del amanecer, ciudad del futuro, ahora}

Resumen. Este artículo describe de manera concisa la formación, el funcionamiento diario y los problemas a los que se enfrenta la ciudad futurista 'Auroville' en el estado de Tamil Nadu en el sur de la India. Fundada en 1968 como ciudad 'universal' y pensada para acoger a 50.000 habitantes, según su fundador supondría un avance en la evolución humana en el sentido de hacer posible la existencia de una comunidad autosuficiente e independiente de los estados nación. Auroville supone un nuevo intento utópico de creación de un espacio ‘comun' que recuerda los anhelos comunistas de arrebatar los bienes comunes de los dominios capitalistas. Exploramos aquí los problemas que encara Auroville cuando produce sus 'comunes' a partir de las tierras de labriegos, reproduciendo de este modo políticas coloniales.

Palabras clave: comunes; comunidades utópicas; colonialismo; India del sur; Sri Aurobindo.

Summary: 1. Introduction. 2. The past's future. 3. The fate of the commons. 4. External pressure and internal conflict. 5. Conclusions. 6. References.

Cómo citar: Parker, I. (2018). Auroville: city of the dawn, city of the future, now, en Teknokultura 15(2): 379-386.

Discourse Unit (Inglaterra)

email: discourseunit@gmail.com 


\section{Introduction}

Auroville is a futuristic city, at least that was the plan, and its fate tells us something about the nature of utopian projects and about 'the commons'. The commons were once our collective natural resources - land, air, water, energy - in the past, and are still there to be reclaimed together for the future. The commons will be ours again, taken from their enclosure as private property, and they ground every communist project. The commons were already there in many attempts to build utopian universal communities around the world, and there are glimmers of the commons now in many places, including in Auroville in south India. At its centre is the Matrimandir (Figure 1), of which more in a moment.

Figure 1. The Matrimandir. Source: our own production

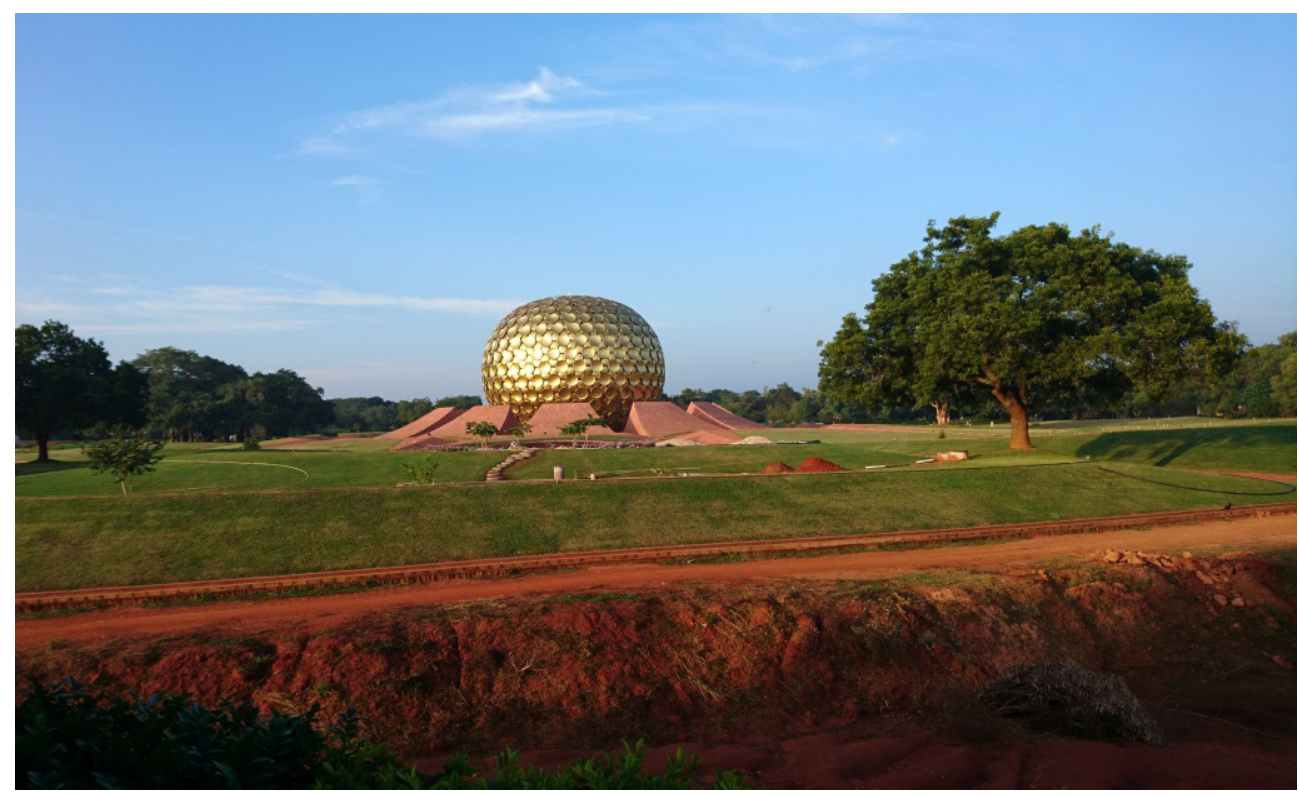

\section{The past's future}

Auroville in Tamil Nadu is a couple of miles north of Puducherry, the old French colonial enclave of Pondicherry, 'Pondi' as it is still commonly known, French until 1962. The new city was set up barely six years after the French left, founded in February 1968. It is marked by its time and place in the history of colonialism and in the post-colonial imagination as an escape from the ravages of capitalism, as is every utopian attempt to implant a community on what is so often viewed as empty land. Auroville made the parched red countryside bloom, and its success and limitations tells us something about the nature of the struggle for the commons today as it celebrates its half-century. The sign on the highway welcomes visitors and invites those confused by the contemporary world to the future (Figure 2). 
Figure 2. Sign for Auroville on the Pondi Highway. Source: our own production

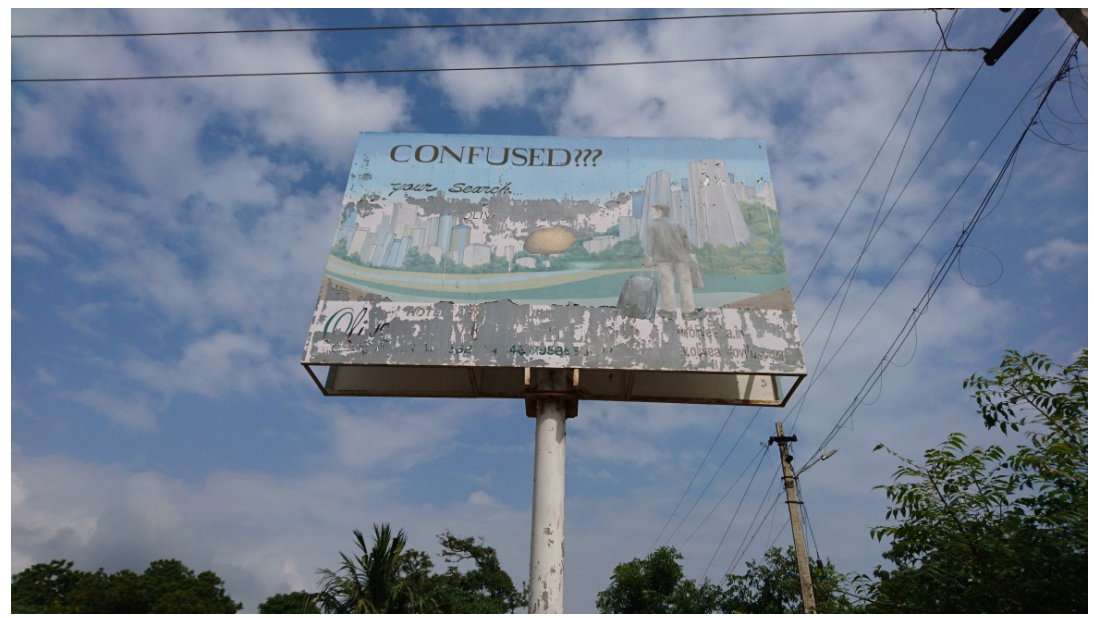

In some strange way this 'city of the dawn' has its roots in anti-colonial struggle. Sri Aurobindo was one of the leaders of the movement against British imperial rule, and took refuge in Pondi in the early twentieth century to avoid arrest, turning to a spiritual life which is commemorated in the Aurobindo Ashram, still there in the French quarter known as 'White Town'. After Sri Aurobindo died his partner Mira Alfassa, a French national from Morocco known as 'The Mother' gathered together followers to keep a legacy alive that would, she claimed, be spiritual, universal, as opposed to religious or ethnically particular. The Mother directed the construction of Auroville, and her image is still very much present there (Figure 3).

Figure 3. The Mother Mira Alfassa. Source: our own production

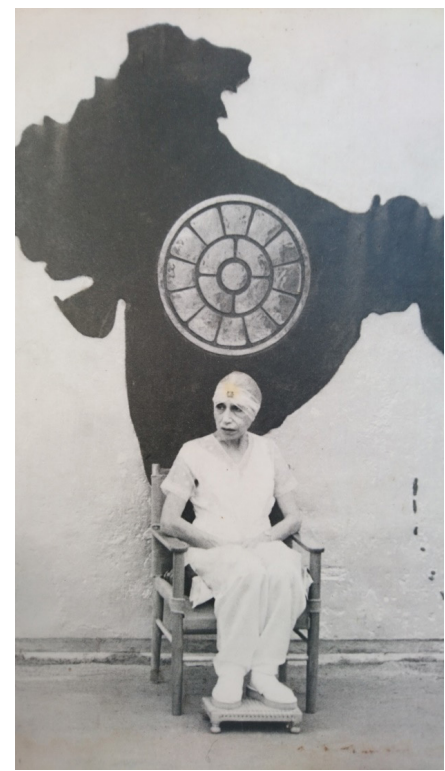


Auroville was founded on 28 February 1968 as a new city that was planned to have 50,000 inhabitants serving, its founding Charter says, the truth of the Divine Consciousness, as a 'bridge between the past and the future' devoted to human unity and belonging to nobody but humanity alone. This new city would link past and future with skyscrapers (one of the signs of high modernity in the 1960s) and electric walkways, self-sufficient with already an ecological consciousness, and so it still does today bring together its citizens, self-defined 'Aurovillians', from nearly fifty countries. It has taken root as a new commons on Tamil land.

\section{The fate of the commons}

In some ways Auroville expresses the hopes of early resistance to enclosure of land, insisting that no single person should have private ownership of it, hopes that were present in communities around the world, and in the heartland of British colonialism in the Diggers movement. The claim to the commons today speaks of anti-colonial and anti-capitalist struggle across Latin America, keys into the specific and universal struggles of women, and so the claim to the commons is also a feminist claim.

These hopes are expressed in the discontents of liberal researchers, with 'commons' as an index of refusal of enclosure in academic life, and in the ideological battle over the supposed 'tragedy of the commons', the false lesson drummed into us that the commons will always be destroyed by competitive individual interest; the commons are at the core of red green politics. It is clear that the commons have to be seized back in common struggle which is also necessarily feminist and anti-colonial struggle, and that this endeavour cannot be quickly bypassed by taking supposedly empty land and building the future there. Our future is always haunted by the past, by the commons, including in Tamil Nadu.

Figure 4. Scale model of Matrimandir in the Visitor's Centre. Source: our own production

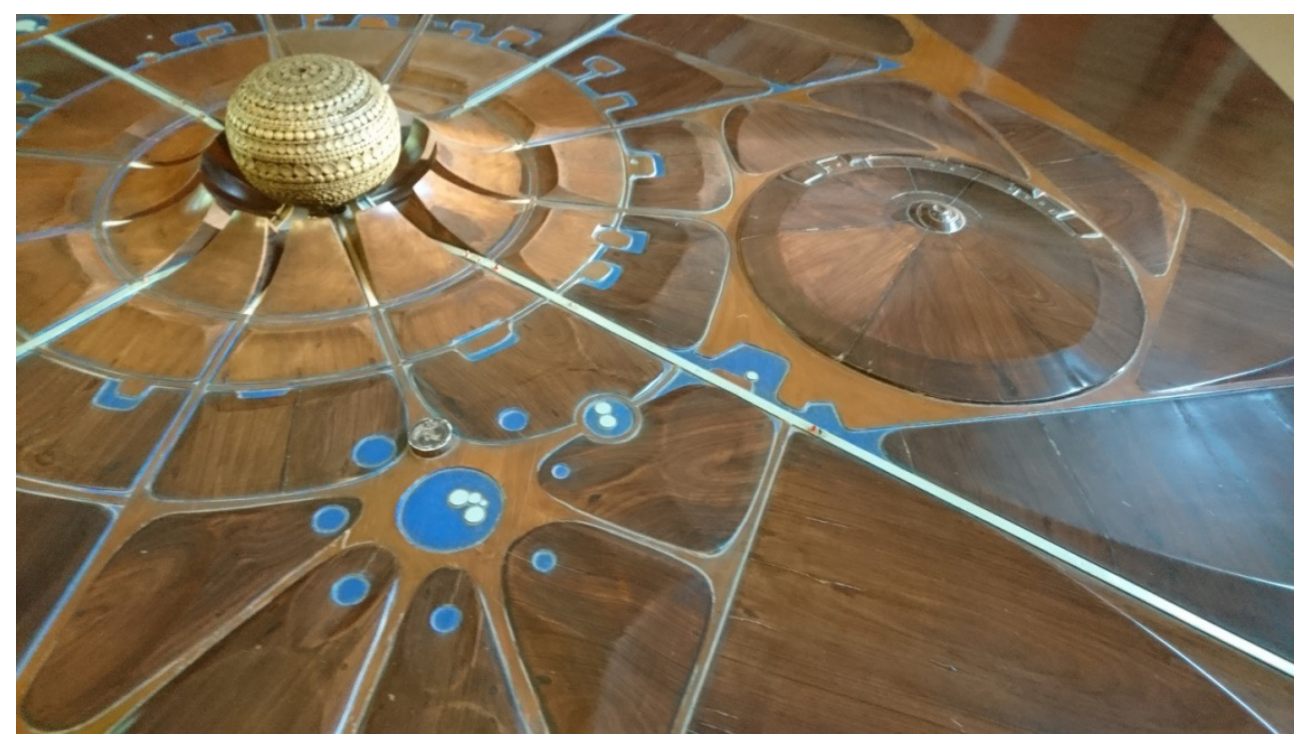


Auroville was blessed with the approval of liberals in the late 1960s. The inauguration of the science-fiction city which was to have a golden globe at its centre - the Matrimandir which appears in the publicity sent out to lure new settlers in (and completed just as The Mother left her physical body) - was attended by world leaders, including from India, who were flown free of charge by Air France, and it was soon recognised by UNESCO. There is a scale model of the Matrimandir in the Visitor's Centre (Figure 4).

The plan of the inside of the Matrimandir shows the two winding walkways that lead visitors from the base of the sphere to the central meditation chamber at the top (Figure 5).

Figure 5. Plan of the inside of the Matrimandir. Source: our own production

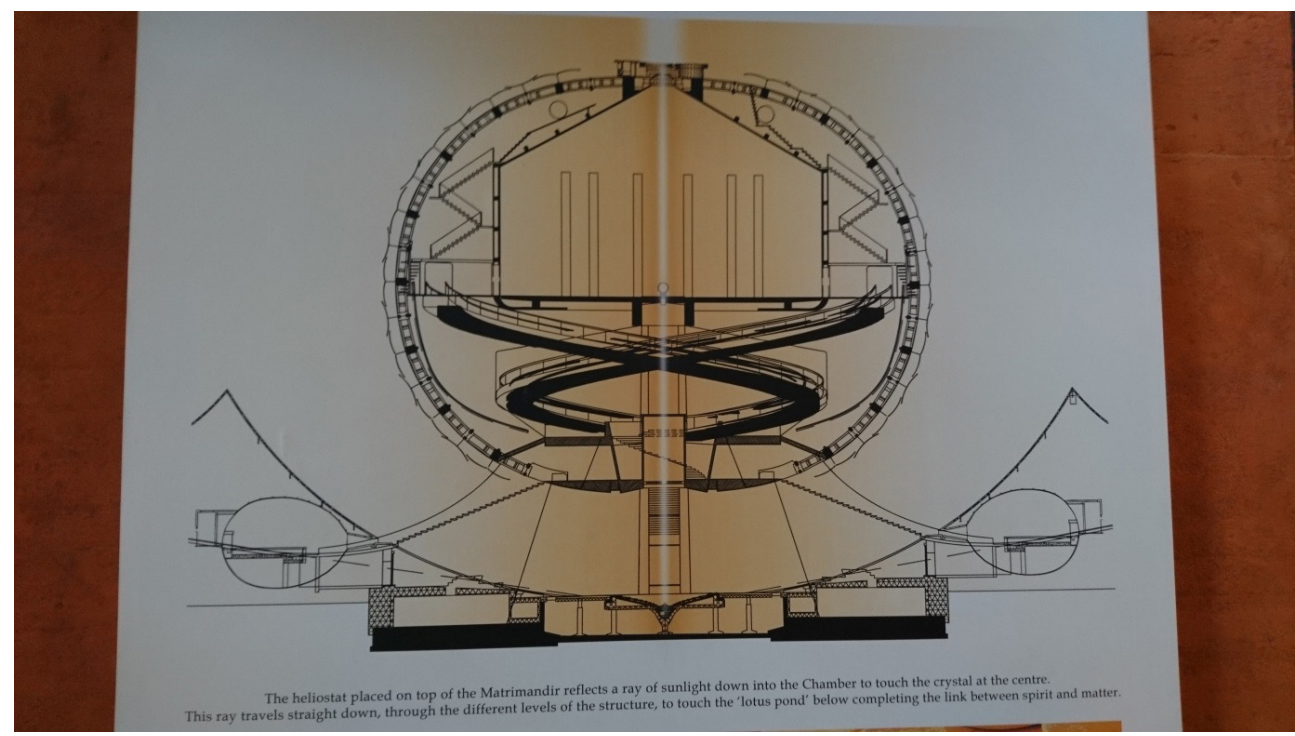

The land was bought from residents of 14 Tamil villages, and there have been sustained efforts to bring locals as well as foreign settlers together through schools and development projects. The break with religion, and a drive to universality that might even also be secular, was later formalised in a split with the Pondi Ashram. There were disputes over the governance of Auroville. The Indian government stepped in so this part of Tamil Nadu now has separate Indian State administrations not only for the Union Territory of Puducherry (a special deal brokered to lever the French out in 1962) and Kalpetty nearby (another former French enclave which is now the site of the University of Puducherry) but also for Auroville itself.

\section{External pressure and internal conflict}

One of the stories told by Aurovillians today is that everything changed after the 2004 tsunami which immediately left 7,000 dead on the nearby coast, and which 
Auroville mobilised for in a number of different projects focussed on the area around Serenity Beach. But it is not clear that everything was perfect before then. There were already conflicts between Tamil residents of the main village Kuilapalayam which adjoins the Auroville central area, refusal by Tamils unwilling to redefine themselves as the kind of universal subjects Auroville desired them to be, unable to afford the fees demanded to buy into what was held out as a common universal future on land that had been bought from them.

To become Aurovillian is not easy; apart from the money, proof of economic self-sufficiency as well as a down-payment on allotted accommodation, there is a two-year probationary period during which time there is assessment of how well the applicant fits with The Mother's dream-scape. There are now just under 3,000 Aurovillians, quite a deal less than the 50,000 projected, and in early 2018 resources were being poured into preparations for the fiftieth anniversary celebrations when Hindu nationalist Indian prime minister Modi faced some harsh questions about what the place is giving back in return for the generous state subsidies for so many Westerners, whether or not they think they have left the West.

The concordance with the Indian state which is devoted to neoliberal development as well as to the fuelling of hatred against religious minorities was problematic enough back in 1968, and now it may well operate as the final dose of poison that pretended to be a remedy. The drip-drip poison of enclosure has been present from the start, and there are plenty of quasi-state administrative measures in place to prevent this being dealt with. There are elections on the basis of personal choice and personal networks, but no parties, no policy differences aired and no platforms for change, something which runs alongside the prohibition on religion. There are also assembly meetings, but very little collective debate, and today the different national groups speak with each other rather than across the community in what should be the dialogical basis of the commons.

The most recent estimates are that there are nearly 400 French-origin Aurovillians, just over 200 German, 150 Italian, and then under 100 Dutch, American and Russian, with most other nationalities represented in single figures. There are over 1000 'Indians', the largest group, but these are lighter-skinned middle-class origin citizens who were able to buy their way in. This colonial enclosure of Tamil village land is, in some senses, internal colonial enclosure as well as the expression of a Western neo-colonial dream. The Tamil villagers, of which 6,000 work in Auroville servicing the community, are being pressured to sell more of their land, something they resent, and there is a rise in crime which some blame on Kuilapalayam village.

The Indian citizens of Auroville are Hindu, and there are images aplenty in the private spaces as well as in the public entrepreneurial projects which help fund Auroville. Aurovillians are permitted to bring whatever religious symbols they wish into their own homes. The only Muslim Aurovillian has recently died, and so 'universal' here is another particular sign of enclosure (apparently The Mother did not like Islam). This implicitly Hindu religious iconography which is prevalent around the public grounds of the Auroville complex is subordinate, however, to evolutionary utopian science-fiction semiotic promotional advertising (Figure 6). 
Figure 6. Auroville promotional DVD cover. Source: our own production

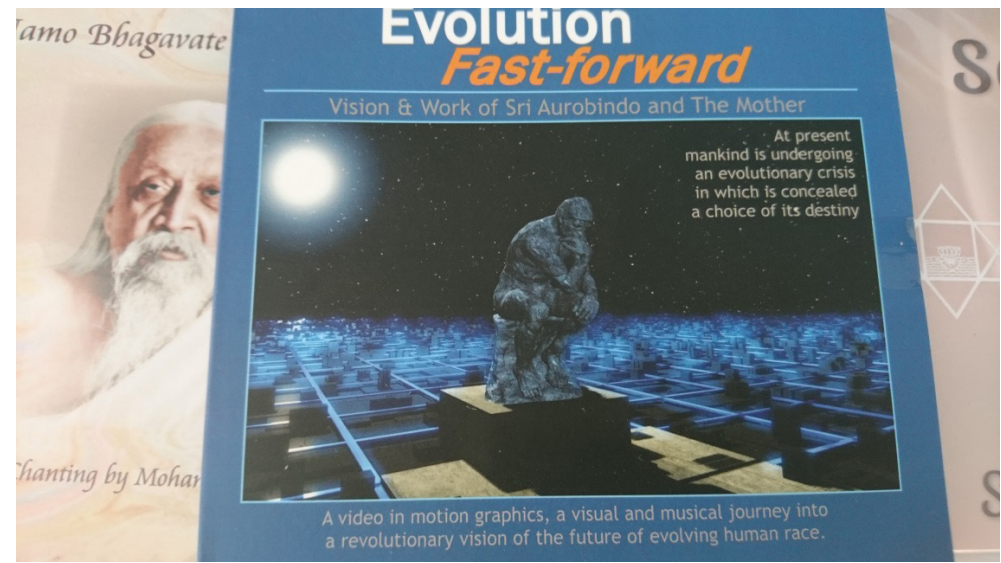

The narrow dirt track paths are being replaced with brick and tarmac roads - the main one of which was ready to welcome Modi - and there has been an exponential growth of private cars since the tsunami, private cars and mobile phones and even, hard for a 1968er to comprehend, separate gated communities. And the ecologists are on the back foot, with a proliferation of throwaway non-recyclable goods appearing in Auroville. It seems that on this common land which was bought from Tamils and enclosed to protect itself from the Tamil villagers, and whose labour it relies on to keep going, there are few common projects. Instead it is every man for himself, expected to live and let live and, better, encouraged to be an entrepreneur with a business from which a sizeable cut will go to the central authority. Businesses now include Australian spirulina, Austrian paper, Israeli wind-chimes and Tamil dolls (all of these national designations dissolved, of course, into an overarching 'Aurovillian' universal identity, and a host of organic cafes for the tourists who come to marvel at what has been done and what may be. The futuristic architecture of Auroville speaks of the hope of the commons but also of enclosure, a paradox built into the land. There is a simple graveyard with futuristic marble monuments surrounded by grassland

Figure 7. Auroville graves. Source: our own production

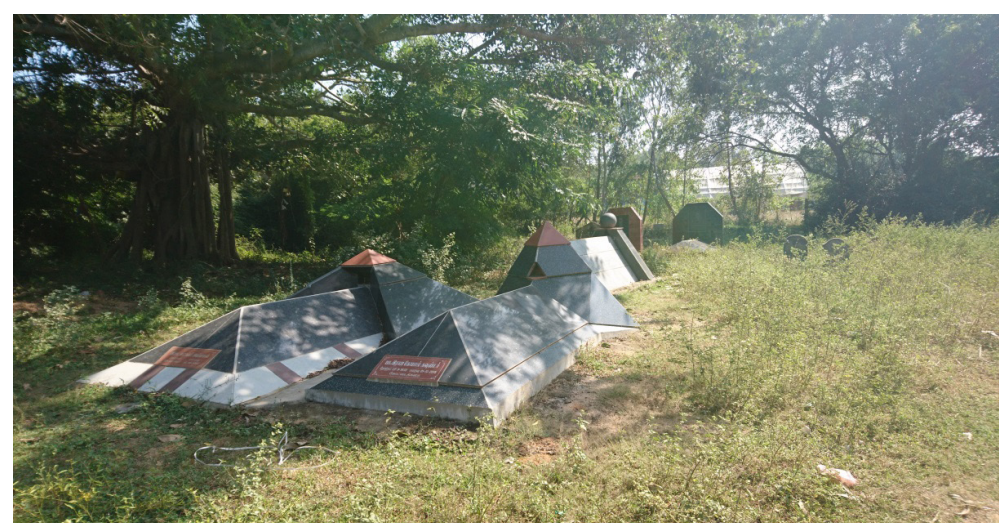


Figure 7. Auroville graves. Source: our own production

\section{Conclusions}

How do we make sense of this place? There are some clues nearby. There is a Romain Rolland Library in Pondi with stacks and piles of disintegrating books. French author Romain Rolland (who corresponded with Freud), was a Western intellectual whose own local legacy in the library, common space for reading and writing and debating, is itself precarious in neoliberal times. Among the books on the shelves is a copy of the Samuel Smiles 1859 classic Self-Help. Samuel Smiles was an active supporter of the Chartists in the early nineteenth century but drifted toward Victorian liberalism, and his book Self-Help is a celebration and injunction for citizens in capitalist culture to pull themselves together so that all that would be left of the hope of the commons would be a collection of individuals and interest groups. So it is with Auroville, from its radical past, such as it was, the limited room for manoeuvre it had is being closed down, enclosed. The lesson being that you can't just create the 'commons' anywhere you like as some kind of giant self-help project; you have to do it as a common project that actively includes all of the oppressed to claim what is ours of right on this earth.

\section{References}

Majumdar, A. (2017). Auroville: A City for the Future. New York: Element.

Minor, N. M. (1999). The Religious, the Spiritual, and the Secular: Auroville and Secular India. New York: SUNY Press.

PRISMA AUROVILLE (2016). The Auroville Handbook. Auroville: Prisma.

Smiles, S. (1859). Self-Help; with Illustrations of Character and Conduct. London: John Murray. 